Meta

Journal des traducteurs

Translators' Journal

\title{
History and Policy of Translating Poetry: Azerbaijan and Its Neighbors
}

\section{Hamlet Isaxanli}

Volume 59, numéro 2, août 2014

URI : https://id.erudit.org/iderudit/1027478ar

DOI : https://doi.org/10.7202/1027478ar

Aller au sommaire du numéro

\section{Éditeur(s)}

Les Presses de l’Université de Montréal

ISSN

0026-0452 (imprimé)

1492-1421 (numérique)

Découvrir la revue

Citer cet article

Isaxanli, H. (2014). History and Policy of Translating Poetry: Azerbaijan and Its Neighbors. Meta, 59(2), 310-329. https://doi.org/10.7202/1027478ar
Résumé de l'article

Tout au long de l'histoire des civilisations, l'art de la traduction a servi de pont reliant les différentes cultures régionales. Cet article porte sur l'histoire de la traduction de la poésie (et d'autres types de littérature) au Moyen-Orient et dans les territoires attenants à l'Azerbaïdjan du Moyen Âge au XX ${ }^{\mathrm{e}}$ siècle. Nous procédons également à un examen de la pratique de la traduction des livres saints et de son influence sur la région à l'étude, ainsi que de la tradition du nezire, qui consiste en l'écriture d'un nouvel ouvrage à partir d'un original plutôt qu'à traduire ce dernier. La deuxième partie de l'article aborde l'histoire de la traduction de la poésie en langue azerbaïdjanaise et à partir de celle-ci, en particulier le travail de traduction d'Abbas Sehhet et de Samad Vurghun, deux traducteurs renommés dans l'histoire de l'Azerbaïdjan. La dernière partie de l'article examine et analyse différents aspects importants de l'art de la traduction de la poésie, tels que les formes poétiques, les métaphores, le rythme, les rimes et le style du texte. En dernier lieu, nous faisons valoir que la poésie doit en effet être traduite, mais que les traducteurs doivent tenir compte de nombreux facteurs dans leur travail s'ils veulent, autant que faire se peut, transmettre la beauté du texte original dans la langue cible.
Ce document est protégé par la loi sur le droit d'auteur. L'utilisation des services d’Érudit (y compris la reproduction) est assujettie à sa politique d'utilisation que vous pouvez consulter en ligne.

https://apropos.erudit.org/fr/usagers/politique-dutilisation/ 


\title{
History and Policy of Translating Poetry: Azerbaijan and Its Neighbors
}

\author{
HAMLET ISAX ANLI ${ }^{1}$ \\ Khazar University, Baku, Azerbaijan \\ hamlet@khazar.org
}

\begin{abstract}
RÉSUMÉ
Tout au long de l'histoire des civilisations, l'art de la traduction a servi de pont reliant les différentes cultures régionales. Cet article porte sur l'histoire de la traduction de la poésie (et d'autres types de littérature) au Moyen-Orient et dans les territoires attenants à l'Azerbaïdjan du Moyen Âge au XXe siècle. Nous procédons également à un examen de la pratique de la traduction des livres saints et de son influence sur la région à l'étude, ainsi que de la tradition du nezire, qui consiste en l'écriture d'un nouvel ouvrage à partir d'un original plutôt qu'à traduire ce dernier. La deuxième partie de l'article aborde l'histoire de la traduction de la poésie en langue azerbaïdjanaise et à partir de celle-ci, en particulier le travail de traduction d'Abbas Sehhet et de Samad Vurghun, deux traducteurs renommés dans l'histoire de l'Azerbaïdjan. La dernière partie de l'article examine et analyse différents aspects importants de l'art de la traduction de la poésie, tels que les formes poétiques, les métaphores, le rythme, les rimes et le style du texte. En dernier lieu, nous faisons valoir que la poésie doit en effet être traduite, mais que les traducteurs doivent tenir compte de nombreux facteurs dans leur travail s'ils veulent, autant que faire se peut, transmettre la beauté du texte original dans la langue cible.
\end{abstract}

\section{ABSTRACT}

Throughout the history of civilization the art of translation has existed as a bridge that connects different cultures. The article focuses on the history of poetic (and other) translations in the Middle East and territories abutting Azerbaijan from the Middle Ages to the $20^{\text {th }}$ century. It also explores the practice of translating holy books and its influence on the region, as well as the tradition of nezire, or writing a new book under the inspiration of an original one rather than simply translating the original. The second part of the article discusses the history of poetic translation into and from the Azerbaijani language, especially translation work from Abbas Sehhet and Samad Vurghun, two renowned translators in Azerbaijani history. Finally, important aspects of the art of translating poetry are reviewed and analyzed, such as poetic forms and metaphors, rhythm and rhyme schemes, and the style of the text. The article concludes by making the point that poetry should indeed be translated; however, translators must take many factors into account in their work so that the target text reflects as much as possible the beauty of the original.

\section{MOTS-CLÉS/KEYWORDS}

traduction, poésie, Azerbaïdjan, Moyen-Orient, culture. translation, poetry, Azerbaijan, Middle East, culture.

\section{Introduction}

Through the history of civilization the art of translation has existed as a bridge joining different cultures. This art in particular ensures the establishment of later cultures on the achievements of former ones. In the $9^{\text {th }}$ century a great translation center named Beytul-Hikmeh [House of Wisdom] functioned in Baghdad. Caliphs Harun 
al-Rashid, Al-Mamun and Al-Mansur, viziers and other men of power were also men of charity; they willingly and passionately assisted the development of translation activities. Muslims began to appropriate, interpret and develop what they had heard, felt, and were partly aware of - the intellectual heritage that mankind had gained for about a thousand years - with the help of extensive translations.

A few centuries later, intercourse with the Muslim world played an important role in the revitalization and rise of Europe. Europe had no civilized neighbors other than the Muslim world. When European interest in studying and working increased, it was clear from whom and how to study. Side by side with European scientific and economic formation, the European identity and European self-conscience were determined in the process of rivalry and competition with the Muslim East. In the $12^{\text {th }}$ and $13^{\text {th }}$ centuries in Toledo and in some other places, the achievements of Islamic science and culture began to be translated first into Latin, then into Spanish and other European vernacular languages. Translation activity spread widely. The translations in the $13^{\text {th }}$ century of that period (particularly Calila e Dimna and the collection of legends connected with Sinbad from The Tales of 1001 Nights) played a great role in the formation of Spanish, Portuguese, Provençal and other literatures. If not for the influence of these translations, neither Robinson Crusoe nor Gulliver's Travels would have been written (Arnold and Guillaume 1931: 201).

The purpose of this article is to address certain characteristics of poetic translation in Azerbaijan, and by necessity the broader region, such as the Middle East and Russia, as well as some specific circumstances and experience in the translation of poetry. In describing the history of the problem I will touch a little upon the translation problem as a whole as well. The Routledge Encyclopedia of Translation Studies (Baker and Saldanha 2009) contains a general overview of translation theory and history as well as translation studies within various world regions. Particularly, three regions with Islamic heritage were considered: the Arab world, Iran and Ottoman Turkey. The Muslim Indian subcontinent is encountered episodically, and nothing is mentioned of the Malay world. The Muslim world of the Caucasus, particularly Azerbaijan as well as all of Central Asia and the Tatars of the Volga River basin and Crimea regions, which may be named the North Eurasian Muslim civilization, or Russian Muslims if the $19^{\text {th }}$ century and ensuing years are considered, remains untouched by this Encyclopedia. However, these Muslims of Russia led the process of modernization, or were at least a leading group among Muslim peoples, in many areas. M. F. Akhundov, Mirza Kazim bey, H. B. Zardabi, I. Qasprinski, U. Hacibeyli, A. Huseynzade, Y. Akchura, A. Topchubashi, A. Aghaoghlu, C. Mamedquluzade, and M. A. Rasulzade were pioneers of dramaturgy and theater, in synthesis of European and Oriental music, journalism, education, Turanism, and social/democratic movements beyond just the Russian Muslim world; they strongly influenced the modernization process of Ottoman Turkey and partly Iran. Some of them translated European literary, business and political works into Azerbaijani, Turkish, Persian, Russian and vice versa.

History and culture, politics and economics of any nation or country cannot be understood, appreciated or evaluated in isolation from the surrounding civilizations. Azerbaijani people and their territories (their semi-independent or autonomous states) have been part of the Middle East with its Islamic caliphate, Seljuk, Mongol, Qaraqoyunlu, Aghqoyunlu, and Safavid Empires. They became the subject of heated 
debates and wars between Iran, the Ottomans, and then Russia, so the Azerbaijani (or Azeri) people ended up a divided nation after the 1828 Turkmenchay Treaty was signed between Russia and Iran. A minority of the Azerbaijani people remained in Russia (as Northern or Caucasian Azerbaijan), and the majority in Iran (as Southern or Iranian Azerbaijan) (Altstadt 1992: 74-107). The short-lived independent Democratic Republic of Azerbaijan (28 May 1918 to 28 April 1920) was replaced by the autonomous Azerbaijan Soviet Republic as one of the Soviet Union republics, and the latter was replaced by the independent Republic of Azerbaijan (1991) as a result of the collapse of the Soviet Union and the whole socialist bloc (Swietochowski 1995: 56-103).

While my purpose is to elucidate the history and methodology of translation activity concentrated in Azerbaijan, I must also discuss various other geographical and historic contexts to give a full understanding of the Azerbaijani situation. This additional background information is necessary not only for contextual clarification but also for the simple reason that borders in the Middle Ages were different from modern borders. Azerbaijani poets (and translators) lived, wrote and died in the Caucasus, Iran, Syria, Baghdad, Anatolia, India, and Russia.

\section{Translating Poetry}

Spreading and passing on knowledge and scholarship from one country and/or scientific center to another is a decisive work in the development of mankind which throughout history had to be done mainly by translators, many of whom also became scholars.

Muslim schools of translation remained indifferent toward works about religion and history, and they did not translate poems or plays from Greek. While translating works from literature, they looked to the East. Nevertheless, there was a problem with translating the poems that translators came across in writings on philosophy and other fields. Arabian writer and scholar al-Jahiz (776-868/9) wrote:

Poems don't stand translations; they don't have to be translated. While translated their poetical structure is broken; their measure and harmony of rhythm are lost. Poetic beauty disappears. There remains no grace to the poem. But the situation in prose is different. (Rosenthal 1994: 18)

Poetry is a grace that springs up from the poet's fantasy and the uniqueness of a language's inner beauty, power and energy, and by means of colorful idiomatic expressions that have been accumulated over hundreds, even thousands, of years. To what extent is it possible to express an original text's beauty in a target language?

The beauty of poetry is the phenomenon of language. Fine poetry, especially pure national poetry, seems to be difficult to copy into other languages while maintaining the same content and strength. Differences between poetic traditions are much deeper than differences in prose styles.

Dryden likened the difficulty of translating poetry figuratively to "dancing on ropes with fettered legs: a man may be cautious not to fall, but in this case, gracefulness of motion is not to be expected of him" (Dryden 1992: 18). Another figurative saying belongs to Akhmatova (1986: 441): "It is known that if the rhymes are wings in your own poems, they turn into heavy dumb-bells during translation." 
How much is it necessary to be loyal to the original, and what does the word "loyal" mean? How must the poetic tradition of the target language be taken into account? Is it important to use rhymes in a poem's translation? There are many questions without direct answers.

\section{Translation of Poetry and Nezire in Azerbaijan and Around: Middle Ages}

In the $12^{\text {th }}$ and $13^{\text {th }}$ centuries Azerbaijan scholars carried out research in medicine, philosophy, theology, mathematics and astronomy, and there was a strong interest in literature, especially in poetry. Alongside poetry, other forms of literature such as dastans [sagas], which were usually accompanied by poems and musical performance, were also spreading and appreciated by people across languages. But in poetry, direct translation into other languages was not so widespread.

The Azerbaijani poet Nizami Ganjavi (1141-1209), one of the colossal figures in classical poetry in Persian, in his qaside [ode] "Renewal of Matlain," noted sharp differences between the translation of scientific texts and poetic works. The words of scientific texts "can change their clothes, can keep their meaning by putting on another dress," that is, by translating the words and phrases, the text can be restored again in the target language - the dress (language) has changed; the meaning has not. However, considering poetry, it is impossible to simply "put on another dress." (Ganjavi 1983: 35). Lyrics in other words, translated poetry cannot be equivalent to what was in the original.

One very commonly employed technique was writing nezire, an imitative poem under the direct influence of a well-known poem, instead of translating or writing one's own independent work. This was done by making changes and additions to the original prominent poem. In nezire, the topic and content might be very close to the original; there might also be great similarity in form. Attention was not paid to plagiarism in its literal meaning (Von Grünebaum 1981: 127-156). Von Grünebaum speaks about a phenomenon observed in Arab poetry: "meaning is common, it is aggregate property of all wise men” (Von Grünebaum 1981: 132). He notes that respect for forefathers in Arab poetry is superior to respect for originality.

But there were those who noticed this problem of nezire and were concerned about it. While condemning those who stole some of his works, Nizami consoled himself, recalling his own richness in poetry: "He steals, but I melt away because of my being ashamed [...]I have got the treasury of the two worlds [...] It is necessary for me to give alms to the poor" (Ganjavi 1192/1981: 49). The greatest nezire literature in Persian and in various Turkic languages was developed by using topics and plots from Nizami's Khamsa [Five Poems].

The famous polymath, founder of Maragha (a city in Azerbaijan, south of Tabriz) Observatory and the "Maragha School" in Astronomy, Nasiraddin Tusi (1201-1274), was asked to translate the work At-Tahare by the Arabian author Ibn Misgaveh into Persian. The work, as a mirror for princes, was about the refining of morality. But instead of translating that work, Tusi considered it more appropriate to write a book improving on At-Tahare, including two new issues not mentioned by Ibn Misgaveh. Thus the work Akhlaqi-Nasiri [Nasir's ethics] came to life and became famous. A quote from this work shows Tusi's opinions on translation: "To translate all these fine 
meanings, to undress the nice dresses of the meanings, to cause them to put on old used clothes gives the impression of making a man look like a monkey. A man of taste will scoff when seeing it" (Tusi 1989: 34). Both At-Tahare and Akhlagi-Nasiri were written in a prosaic way. This shows that even to translate a work written in prose was considered to be a matter of less esteem than to write one's own work with large borrowings from previous authors.

Thus, translators in the Muslim world of the Middle Ages dealt freely with the original text, even changing the topic and length of the work; in some cases the translation was two to three times larger than the original. For instance, translator Vali Shirazi doubled the volume of the original Persian mystic poem Gulshani-raz by Mahmud Shabustari in his Azerbaijani translation (Nağısoylu 2000: 72-75). The great extent of freedom in translating was perhaps connected with the desire to demonstrate the translator's identity. Current opinions about some creative works of the Middle Ages differ as to whether they are originals or translations. The most cited work on this issue is Hadiqat as-Suada by M. Fuzuli (1483-1556), which remains the subject of debate regarding its identity as an original or as a translation from $\mathrm{H}$. V. Kashifi's (n.a. - 1505) Rovzat ash-Suhada (Nağ1soylu 2000: 36-40).

Starting from the $13^{\text {th }}$ century, bilingual and trilingual translation dictionaries of the Azerbaijani language were compiled. In order to comprehend texts written in Arabic and Persian, satiraltı tarcüma, or interlinear translations, were used to show the word for word glosses in Azerbaijani under each line of original text. Aghqoyunlu monarch Uzun Hasan ("Long” or “Tall” Hasan) commissioned an interlinear translation of the Qur'an into his native Turkmen-Azerbaijani language (Isaxanli 2008: 69-70). The Qur'an and the famous moral poem Gulustan by Sadi Shirazi were the two most translated texts into Azerbaijani using the interlinear method during the Middle Ages. Both of them were used in schools and madrasahs as textbooks, and the latter also played the role of a unique textbook for learning Persian.

Azerbaijani mystic Hurufi poets Nasimi (1369-1417) and Fuzuli were also involved in creative, free translation. In some cases, they (and others) translated epic poems into the target language in a prosaic way. The purpose of such translation was to draw attention to the content of the original or to preserve this content. In the following centuries, along with an increase of translations, their scope also became wider, including translations of belles-lettres, arithmetic, medicine, history, and geography. However, the typographical method of publishing did not come into popular use in the Muslim East until the $19^{\text {th }}$ century. The scope of public education was also very narrow. Therefore, these translations were not able to play a great role in changing society.

\section{Translating Holy Books: The Qur'an}

The leading role of translation in the development of language is another substantial subject for consideration. D'Alembert stated that “[m] onumental translations are the fastest and most reliable way to enrich a language" (D’Alembert, "Observations sur l'art de traduire," cited by Delisle and Woodsworth 2012: 21). Translations of holy books directly served both to spread religions and to standardize terms in the languages into which they were translated. However, one can see that these services and influences had different characteristics in the East than in the West. 
From the very outset, the holy writings of Buddhism had been written in Pali, Sanskrit, Chinese and Tibetan languages, and there was no concept of having a primary holy language. Therefore, nothing could prevent the translation of holy books into other languages (Delisle and Woodsworth 2012: 184). By the $7^{\text {th }}$ century, Buddhism was a leading religion among Turkic-speaking Uyghurs and it was able, according to Caferoglu, to influence both the development and the disordering of their language: "The translations, which had taken a great place in the Uyghur language, clearly influenced the Uyghur dialect and style" (Caferoglu 1984: 152). At the same time, translators belonging to different translation schools "were behind the subdivision and separation of the Uyghur literary language into various dialects" (Caferoglu 1984: 158).

In the Middle Ages of the Muslim East, the posture of translation of the Qur'an was different from that of the Christian World. Translation of the Qur'an did not strongly stimulate the development of vernacular languages, including Azerbaijani, in contrast with the cases of translation of the Bible by Martin Luther into German and by William Tyndale into English. The Qur'an was “A scripture whereof the verses are expounded, a Qur'an in Arabic for a people who have knowledge" (Pickthall 1992: Qur'an 41:3), meaning that it was Allah's word in Arabic: "Lo! We have revealed it, a Qur'an, that ye may understand” (Pickthall 1992: Qur'an 12:2). Arabic left no room for a rival language in theology, and it was also heavily dominant in science and culture. In the Middle Ages it was advised only to write explanations and interpretations (tafsir) of the Qur'an. At that time some commentary-translations of the Qur'an did appear in various Turkic languages, including Azerbaijani. One example is the translation by Muhammad Dövlətşah Şirazi completed in 1333 (Isaxanli 2008: 104). In Azerbaijan, comprehensive explanatory translations of the Qur'an began at the start of the $20^{\text {th }}$ century (there are at least two published translations, one by Mir Muhammad Karim Mirza in Baku and another by Muhammad Hasan Mawlazade Oakwi in Tiflis) (Isaxanli 2008: 71). On the eve of the disintegration of the Soviet Union, translations meeting general standards were published. ${ }^{2}$

The Qur'an's features, including beauty and indescribably fine shades of meaning peculiar to Arab poetry before Islam, necessitate looking at the issue of translation of the Qur'an into other languages not as a simple translation of a religious-philosophical text, but also as an issue of poetic translation.

\section{Translations into Western languages: Beginnings}

Starting from the early $19^{\text {th }}$ century, Azerbaijani literature entered a period of being studied and becoming known in the West and in Russia; Azerbaijani and Turkic folklore and samples of written literature began to be translated into the main Western languages.

European doors to Azerbaijani literature were first opened in Germany in 1814. H. von Diez (1751-1817) discovered the manuscript of Kitab-i Dedem Qorqud in the Royal library of Dresden. He copied it by his own hand, translated a boy [chapter] named Tapagoz (a man with one eye on the top of his head) into German, and published it in 1815. That was also the first step in Dedem Qorqud studies (Schmiede, Aliyarli et al. 2002). In 1818 Joseph von Hammer translated some passages of Nizami Ganjavi into German and informed Europe about his life and literary activity for the 
first time. In 1819, J. W. Goethe published the West-East Divan; there he led a discussion both about a legend connected to Kitab-i Dedem Qorqud and about Nizami. Shortly thereafter, translation and investigation of Nizami's works began in French-, Russian- and English-speaking countries (Krimskiy 1981: 42-44). Beginning in 1825, numerous Azerbaijani tales were translated into Russian and published in various magazines.

In 1849, Alexander Chodzko published one version of the Koroghlu (Blind Man's Son) epic in London in English. Writers such as George Sand, who wrote “j”insiste, et je dis: Lisez Kourroglou; c'est amusant, quoique ce soit beau" 3 and Longfellow were interested in Koroghlu, inspired by the romantic plots of this epic in writing their own works.

\section{Translations from Azerbaijani Literature, $19^{\text {th }}$ Century}

\subsection{Mirza Kazim bey}

In Russian and Western scholarship, one of the first important steps in the study of Azerbaijani history and language was taken by the eminent orientalist (himself Azeri) Mirza Kazim bey (1802-1870). His contribution to the study of the East was highly appreciated by contemporary scholars of that time. He was elected as a member of the American Philosophical Society. ${ }^{4}$ Russian orientalist V.V. Grigoryev introduced Kazim bey as follows:

At present, he is one of the distinguished personalities not only in Russia, but also in Asia and all over Europe. He is an Asian who has united deep Muslim education with European scholarship that he is thoroughly familiar with. Mirza Kazim bey has learned Arabic, Persian, Turkish, English, French and Russian at the same level and wrote and published in each of these six languages. (Grigoryev 1870: 256-257, cited by Rzayev 1989: 44).

Kazim bey prepared and published the critical work Derbend-name, a valuable source on Azerbaijani history, on the basis of various unsystematic manuscripts. He also wrote commentaries to this work in Russian, English and French. This work, and The Grammar of Turkish-Tatar Language (1839), echoed in academic circles as a great contribution to Azerbaijani studies and to Turkish studies in general (Kazem Bek 1985: 234-235).

Side by side with his translations in various academic fields, he also translated Sadi's Gulustan into Russian (1829), and he started to compile an Azerbaijani-Russian dictionary. Unfortunately, these works were never finished (Rzayev 1989: 29, 71, 193). Kazim bey compiled a complete concordance of the Quran, Miftakh Kunuz al-Quran, in Russian in 1859.

\subsection{Freidrich Bodenstedt and others}

German poet and translator Bodenstedt took lessons from M. Shafy Vazeh (17941852) in Tiflis in order to learn languages and to study the East in general. He translated Vazeh's poems into German and published them in 1851 under the name Die Lieder des Mirza-Schaffy [Mirza Shafy's Songs]. These Songs became famous all over Europe in a short time and were translated from German into many languages. From 
1851 to 1873 , Songs was published 47 times in German. Bodenstedt most probably did not expect such an extraordinary interest. In a book that he published in 1874, he declared that the real author of Songs was himself, Bodenstedt, not Shafy. The number of publications of Songs in German reached 169 by 1922 (Seyid-zade 1969: 77-83).

In any case, with his translation, Bodenstedt protected and popularized Shafy's poems, helping them to survive until the present. In the $20^{\text {th }}$ century, the personality and literary activity of Shafy attracted researchers' attention mainly due to the broad dissemination of this translation through Europe and Russia (although very few of Shafy's poems can be found in the original Azeri or Persian). Bodenstedt also translated nine of Bakikhanov's poems and published them in 1864 in a new book as a chapter entitled From the Divan of Abbasgulu Khan. Some of Bakikhanov's poems were translated into Polish and Russian, and published during his lifetime.

Omar Khayyam's work, like that of Vazeh, took on a life of its own in translation. It is interesting that in Hammer's book mentioned in section 5 above, there was information about Khayyam and his 25 quatrains that were published in that book (Krimskiy 1981: 207). But Khayyam's break came with FitzGerald's translation of 75 quatrains into English in 1858 (the book was published anonymously, without the translator's name). At first this translation drew no attention. A second publication of the quatrains in 1875 revealed the name of FitzGerald as the translator. FitzGerald was free in his translation, as he himself wrote: "Many quatrains are mashed together: and something lost..." (Khayyam 1970: i). But he was able to keep Khayyam's spirit and amaze his readers with his mastery in imitation. In the years around 1900 in English-speaking countries, Khayyam's quatrains gained fantastic popularity in FitzGerald's translation - they became a form of mania (Omar cult). This work made the great mathematician and astronomer Khayyam known as a great poet all over the world. The success of the translation was unusual and unexpectedly high; the poems were read and appreciated in broad circles. In 1863 John Ruskin wrote in his letter ${ }^{5}$ addressed to the translator, who was unknown at that time: "My dear and very dear Sir, ...I never did - till this day - read anything so glorious to my mind as this poem..." (The letter was published in Terhune 1947: 212).

The works of some Azerbaijani authors of the $19^{\text {th }}$ century can be found not in the original but in German, Polish, and Russian. Gutgashinli's romantic story Rashid bey and Seadet khanim was published in French in 1835 in Warsaw, and after more than a century, in 1939, it was translated back into Azerbaijani (Qutqashinli 1967).

Akhundzade's five comedies were translated by the author himself and first published in Tiflis (1853) in Russian, not in Azerbaijani. In the $19^{\text {th }}$ century his comedies were translated into some Western, Eastern, and Caucasian languages. His poem The Eastern Poem about A. S Pushkin's Death written in Persian was translated into Russian word for word and was published in the magazine Moskovskiy Nablyudatel' in March 1837. Afterwards, Akhundzade's poem, which he addressed to Qasim bey Zakir and which was devoted to the Ottoman-Russian war, and Zakir's answer to him, were published in the newspaper Kavkaz (1854) in literal translation.

Bakikhanov and Akhundzade translated some of their other works into Russian; unfortunately, they could not publish them because of financial and/or political difficulties. 


\section{Translations into the Azerbaijani language: Abbas Sehhet}

Translations from world literature into Azerbaijani in the $19^{\text {th }}$ century were incomparably few. In 1912, Sehhet wrote: "Europeans have translated famous Arab and Persian writers' works into their own languages completely. In that case, why shouldn't we translate Europeans' works into our language? Why not learn what we don't know?" (Sehhet 1912/1991).

The works of great Persian poets such as Firdovsi, Khayyam, Sadi, and Hafiz were occasionally translated into Azerbaijani, though not on a wide scale. But translations from Western and Russian languages were more interesting, giving poetry completely new breath, new thoughts and new forms. The pioneer of this work is considered to be Bakikhanov, who translated I. A. Krilov's fable Donkey and Nightingale in 1834 (he was also an interpreter in the Russia-Iran negotiation on the Turkmenchay Treaty in 1828). Vazeh also translated one of Veltman's poems from Russian into Azerbaijani. Afterwards, at the end of the $19^{\text {th }}$ and beginning of the $20^{\text {th }}$ century, such writers, poets and educators as S. A. Shirvani, H. Qaradaghi, A. Qanizade, A. Cavanshir, F. Kocherli, R. Efendiyev, and Sabir tried to translate poetry from Russian. But Abbas Sehhet (1874-1918) is considered to be the founder of the Azerbaijani professional school of poetic translation.

Sehhet, representative of Azerbaijani romanticism, was a master in patriotic poetry, scenic lyrics and children's literature. Sehhet's translation work is considered an important branch of his literary activity. Besides the Azerbaijani and Ottoman Turkish languages, he knew Persian, Arabic, French and Russian.

Sehhet was engaged in translation as a serious profession. He was able to reflect the spirit and harmony of the original; his translations were close to the original and rewarding from an artistic point of view. His successes in the field of translation were appreciated by his contemporaries as well as in later periods. Abdulla Shaig writes that " $[\mathrm{u}] \mathrm{p}$ to the present day we haven't met such a true translation in the poetry of Turks as Mirza Abbas's translations. He is the second 'Jukovski'” (Shaig 1912: x, cited by Talibzade 1991: 346). The poet-translator hoped that his translations of poetry would play a role in raising up "new poetry": "I wish that our poets who do not speak foreign languages would write nezires for them and create new fine works, and in this way I want our literature to be enriched and progress" (Sehhet 1912/1991: i, cited by Talibzade 1991: 348).

Sehhet translated French, German, Russian, Ukrainian, Persian, Hungarian, Georgian and Armenian poets. Russian poets, especially from Krylov, Pushkin and Lermontov, had a large place in his translation activity.In 1912, Sehhet published a collection of his translations in two volumes entitled Maghrib Güneşleri [Western Suns]. It was the first collection of poetic translation from European and Caucasus languages. Sehhet was capable of concise writing sticking close to the author's text, but did not restrict himself in his translations. Of course, all his translations are not equal in quality. It is said that Sehhet continued translating after Western Suns, but the remainder of his translations and his own creative works were lost during the chaos of the Armenian-Muslim fight in 1918 and due to his untimely death during the same period. 


\section{Translations from the Azerbaijani language: $20^{\text {th }}$ Century}

The $20^{\text {th }}$ century is considered to be the peak of translation activity in Azerbaijan. Translation work progressed in a planned way in the Soviet period and started to play a great role in the rapid development and revival of scholarship and culture. Translation into Azerbaijani was carried out mainly in two areas: literature (including world literature, classics of Russian literature, and modern works partly based on ideology), and textbooks (including translations and modifications of Russian publications, both prepared using a standardized set of terminology for many academic fields).

Most world literature that was translated into Azerbaijani was done so from Russian (with very few exceptions). Except for scientific terms borrowed from Arabic (like riyaziyyat for mathematics, cəbr for algebra, həndəsə for geometry, tarix for history, ədəbiyyat for literature, cərrahiyyə for surgery, etc.), all other terms borrowed from European languages were used à la Russian. For example, words in Azerbaijani like ensiklopediya, televiziya, funksiya, sosiologiya were used in their Russian forms, not in French such as encyclopédie, télévision, fonction, sociologie (in contrast to Turkish, in which the French articulation of these words was assumed: ansiklopedi, televizyon, fonksiyon, sosyoloji).

Starting from the second half of the 1920s, literary translation activity took on a wide scope in Azerbaijan. One factor ensuring the quality of these translations was the active participation of famous or known writers and poets A. Shaig, Y. V. Chemenzeminli, A. Cavad, C. Cabbarli, M. Rzaquluzade, B. Talibli, A. Mammadxanli, M. Refili, A. Sherif, M. Arif, M. Ibrahimov, S. Vurqun, S. Rustem, M. Mushfiq, R. Rza, R. Sultanov, A. Camil, T. Bayram, A. Kurchayli, and others.

Translation also gained strength in a third direction. The works of Azerbaijani writers and poets were translated into Russian and then from Russian into the languages of other Soviet peoples and also into other foreign languages. Unfortunately, those who translated the works of noteworthy Azerbaijani poets such as eminent Azerbaijani poet S. Vurghun, who had mastered the highest poetical means of expression, managed to maintain the authors' style and beauty only in rare cases.

It seems that few translations were as successful as Simonov's "Vurghun." In Simonov's translations of Vurghun's three poems (Poet, why did you grow so old, so soon?, I am not in a hurry, and Waistcoat), an analogy of Vurghun's inspiration and style are felt, as if Vurghun's breath is observed and his own voice is heard. ${ }^{6}$ Simonov himself called these works free translations, but an attentive reading indicates that he showed respect for the author's text; he did not overstep boundaries in taking poetic liberties while searching for beauty of expressions. ${ }^{7}$

While speaking about the translation of his works into the Russian language, Vurghun says (1943): "a translator must be a creator" and "I cannot say that Adalis, the best translator of my poem 'Azerbaijan,' translates me exactly. At times, he adds some new things to the meaning, but all those have been drawn from my text, from my inspiration." ${ }^{\prime 8}$ Simonov's translations are also of this kind.

Translations of passages of Azerbaijani literature into non-Russian languages were made possible by translating from Russian or by translating from Azerbaijani using preliminary word-for-word translations. Unfortunately, due to most translators' lack of knowledge of Azerbaijani, especially on the level required for translating 
poetry, the spirit of the original was often represented weakly. English-speaking readers who wanted to learn about Azerbaijani poetry had the opportunity to do so mainly thanks to translation projects which were accomplished in the Soviet period. Selections of Azerbaijani poetry covering a thousand-year span and passages from folklore have been translated into English by English and Russian translators and published in Moscow (Ibrahimov 1969). In this anthology, works of Azerbaijani poets who wrote in Persian, starting from Qatran Tabrizi ( $11^{\text {th }}$ Century), who wrote in Azerbaijani, starting from Hasanoglu ( $13^{\text {th }}$ Century), and those who were born up to 1935 have been compiled. Passages of the epics Kitab-i Dedem Qorqud, Asli and Kerem and Qachaq Nebi were also included. A similar initiative was taken in a translation project into French. Luckily, there were translators who knew Azerbaijani, and there are still some at present: Ahmed Schmiede into German, Alla Akhundova into Russian, and Bernard Lewis into English (in his small anthology) are among the most laudable in our time.

Both Schmiede and Akhundova are distinguished by their interest in rich Azerbaijani folklore. They translated the Middle Ages epic poem Kitab-i Dedem Qorqud and Azerbaijani tales into German and Russian, respectively. Here it is worth noting that the last translation of this epic into English belongs to Geoffrey Lewis. Schmiede also translated anecdotes of Khoja Nasireddin (Ankara, 1975) and selected poems (Istanbul,1990) of Baxtiyar Vahabzade (Alimirzeyeva 1999).

Dastans, by their structure, consist of legends in prose and of poems and songs said by the heroes of the dastan-epic. This double structure, and in addition, the changing mood in transition from prose to poetry, makes the translation difficult. The musical rhyme and harmony which are characteristic of the legend/story part of Kitab-i Dedem Qorqud also complicate the translation issue. "The translator of this book, Akhundova, for the first time, was able to achieve the goal of capturing the peculiarity of the work" (Koroghlu 1989: i). As a result of penetrating into languages, folklore and linguistics and by skillfully using the power of her poetic Russian, Akhundova was able to raise her translation up to the level of real Russian poetry. Sometimes she Russifies poems which "are not translatable" because they are affiliated with poetic traditions, phrases, and the language in which they have been written. Her translation of the poem "I asked, she answered" is a good example of this (Isaxanli 2005).

At present, in the translation of Azerbaijani poetry and literature into European languages, it is vital to set up a joint effort of Azerbaijani translators with native speakers; there have been several attempts made in this field as well (Isaxanli 2005).

Relations among national literatures are connected directly with the issue of literary translations. There is a large number of works devoted to Azerbaijani-Russian literary relations. Literary relations between Azerbaijan and other Soviet national literatures, as well as between Azerbaijan and Europe, have also occupied an interesting place in the literary criticism of Azerbaijan (Velikhanova 1994).

\section{Poet and Master of Translation Samad Vurghun}

Samad Vurghun (1906-1956) was one of the leading personalities in $20^{\text {th }}$ century Azerbaijani literature. He became famous among the people to an extraordinary extent; many of his poems are memorized even today. Dozens of his lyric poems, 
poems with patriotic spirit and long epic poems such as Komsomol Poem, Mughan, The Epos of Baku, Aygun, and the verse-play Vaqif, are pearls of Azerbaijani literature. His creativity, often characterized as "mighty, passionate, seething inspiration," and his talent were also broadly spent on glorifying the "building of socialism." (Ibrahimov 1982: 15)

Vurghun made a lasting mark in the field of poetical translation. Three famous epic poems he translated, that is Leyli and Majnun by Nizami (1940), Eugene Onegin by Pushkin (1935-1936), ${ }^{9}$ and A Wrestler in Tiger's Skin by Georgian classic writer Shota Rustaveli (this work was translated from Georgian in collaboration with two other poets, M. Rahim and S. Rustem, in 1936-1937), were appreciated by Azerbaijani readers. According to the opinion of literary critics, these translations, besides demonstrating devotion to the originals, are also comparable to the quality of the originals from the standpoint of their poetic sound. It is necessary to mention that these three classical poems differ from each other in terms of language, poetical style and structure, and the cultural environment in which they were created.

A Wrestler in Tiger's Skin is composed of fully rhymed (aaaa) 16-syllable quatrains. But its hemistiches are written in two forms by means of inner structure, that is to say, inner stress, namely: (1) hemistiches called upper shairi, the structure of which is $4+4+4+4$; and (2) hemistiches called lower shairi, the structure of which is either $5+3+5+3$ or $3+5+3+5$. In both shairi, rhythmical partition (sezura) falls in the middle. Vurghun and his colleagues succeeded in keeping the system of syllable and rhyme as it was in the original by using only upper shair. ${ }^{10}$ This fine work by Rustaveli was spread widely among Azerbaijani readers thanks to these poets' Azerbaijani translations. Vurghun said, in his speech at the anniversary ceremony of Rustaveli: "This great work amazes a man. While working on its translation, I attracted all my feelings, all my inner power, so that it was difficult for me to tear myself away from the work." 11

Ahmed Javad, who had also translated Rustaveli from Georgian (1936), used only the system of rubai, Eastern quatrain rhymes $(a a b a)$. "I dared to sacrifice form for substance. I had to set free each third hemistich of quatrains [...]. This form is more acceptable in our literature." 12 At last, poet and translator Imir Mammadli translated Rustaveli from Georgian into Azerbaijani for a third time; he tried to remain close to the original by keeping the lower shairi as well as the upper. ${ }^{13}$

The love legends of Leyli and Majnun, which began to spring up among Arabian clans before Islam and became well-known in the whole Middle East after the spread of Islam, became an important theme of epic poetry, first in Persian and later in Turkic languages. The most prominent (and earliest) writer in this field is Nizami of Ganja (a city in western Azerbaijan). His successors hailed him as a teacher.

During preparatory events connected with the $800^{\text {th }}$ jubilee of Nizami, Vurghun was given the responsibility to translate Leyli and Majnun into Azerbaijani:

Even the most complicated and difficult senses were translated into Azerbaijani by the poet fluently and compactly. By choosing meaningful words from the rich treasure of our mother tongue, he was able to string them along like pearls. While reading the work it is not absolutely felt that it is a translation. This is a great success, because it has been achieved not by abandoning the original or distorting it, but by exactness, correctness and artistic competence (Ibrahimov 1982: 23). 
Vurghun probably did not face great difficulty in translating Leyli and Majnun because this work was constructed on the rhyme system of traditional classic divan literature, in the genre of mesnevi, consisting of distiches with double rhymes (aa, bb, etc.), which was common to all Eastern people. He would also have been helped by the lexical proximity of Persian to Azerbaijani. As to the existence of definite defects that appear in technical points and some inclinations and differences from the original, these weaknesses do not reduce the quality of the translation.

\section{Eugene Onegin and Azerbaijan}

At present, Pushkin's works have been translated into most languages of the world and even into some languages repeatedly. Bodenstedt, mentioned above, translated Eugene Onegin into German (1854) and at that time, he again won the sympathy of his contemporaries (although V. Nabokov called this translation "naive").

Eugene Onegin has more than thirty translations into English, not taking into account a number of revised translations. Eugene Onegin has been available to English-speaking readers from 1937 to the present in translations by Oliver Elton, Babette Deutsch, Walter Arndt, Vladimir Nabokov, Charles Johnston, James E. Falen and Douglas Hofstadter, Tom Beck, Henry M. Hoyt, Stanley Mitchell, and others. Only Nabokov, who was an inveterate enemy of poetical translation, gave a word-forword semantic translation. Others tried to keep the form and spirit of Pushkin.

Due to ideological reasons, in the former socialist bloc countries the strongest poet-translators were drawn to Eugene Onegin, and it was translated attentively and carefully. Below we will make some notes about the translations of Eugene Onegin by Vurghun.

Translations into Eastern and Asian languages, which remained beyond the Soviet system, were relatively weak. The Sinologist Alekseev called the translation of Eugene Onegin into Chinese by Lyuy In "at the least extent literal, conscientious, but far from poetry" (Alekseev 1985: 256). He pointed out gross errors that made a certain part of the translation look like an anecdote and devoid of the irony that is characteristic of Pushkin's works. For comparison, Alekseev used O. Elton's translation and highly appraised the $28^{\text {th }}$ stanza of the second chapter in English: "My tongue doesn't turn to say that it is equal to Pushkin's work itself, but it comes nearer to it" (Alekseev 1985: 259).

As a final example, the translation of Eugene Onegin into Turkish by Yaran is a careful and orderly translation, which represents the content of the original work completely. However, it is absolutely devoid of rhyme and rhythm. At the same time, the main ritualistic poetic feature of Eugene Onegin is precisely its specific formal sonnet and rhyme system. In the 14 hemistiches of his stanza, Pushkin might come to the end of the stanza with an incomplete thought; the form of the stanza was an important element for him. But according to Yaran, "[i]n the translation, the poem's rhyme cannot be harmonized into the second language."14 From this viewpoint it would be right to call Yaran's useful translation a philological, but not a poetical one.

Vurghun considered the translation of Eugene Onegin one of the achievements of his art and the greatest achievement in his translation activity. ${ }^{15}$ The poet, who realized that the work he carried out was difficult and valuable, was proud of his work: 
I shed pearls of sweat from my forehead

And sacrificed two years of my life.

I turned the masterpiece of the Russian poet

Into the sweet language of Vagif. ${ }^{16}$

In the lines above, he mentioned working on Eugene Onegin for two years, but in one of his articles it is said to be three years (see note 15) and in another article - four years. ${ }^{17}$ His return to this work after the first edition may be explained by his yearning to improve it: "I consider this translation one of my greatest works. I consider that Eugene Onegin must be my original work in Azerbaijani; that is to say, I must be its author with full authority; yes, indeed, its author." ${ }^{18}$ In fact, a successful translation of a work has its own lifecycle independent from the original.

The main text of Eugene Onegin was formed by stanzas (strophes) of iambic tetrameter in the form of sonnets, each consisting of 14 hemistiches. The rhyme scheme of these stanzas is not simple: ababccddeffegg. In the first three quatrains all three rhyme forms which are theoretically possible have been applied: crossing or alternating - abab; neighboring or in pairs (as in distich) - $c c d d$; and closed (circular) - effe. The last two rhymed hemistiches - gg complete the stanza. ${ }^{19}$ Except the introduction of Eugene Onegin, a piece after Tatyana's Letter to Onegin, The Songs of the Girls from the third chapter, and Onegin's letter to Tatyana from the $8^{\text {th }}$ chapter, the stanzas (strophes) used in the poem use the rhyme scheme ababccddeffegg.

In order to translate this masterpiece of Russian poetry into their own language, there was an ongoing competition among poets, especially those of the Soviet Union and the Eastern Bloc countries, where Soviet ideology was dominant. As a matter of fact, in these authoritarian republics and countries, the anniversaries of poets like Pushkin and the translation of their masterpieces into national languages were considered a highly important work at the state level. These kinds of works were planned beforehand with great attention and responsibility. Works such as Eugene Onegin were translated only by prominent poets upon the orders of governments.

Vurghun translated Eugene Onegin during the years 1935-1936. During these years he worked on his own masterpieces as well, including dozens of fine poems that were substantial from an artistic standpoint. His nine long poems and the main chapters of the famous Komsomol Poem were also written in this period. Most likely he began to think about translation of Rustaveli at that time as well.

Of course, in any translation of a monumental and complex work, there may arise weaknesses, disputed points, and technical defects. Part of these weaknesses usually arise due to being under compulsion to finish the work within a limited timeframe. Some defects may happen because of fatigue of the poet or longing to work on his own poetic creation:

There were days when I thought that it is time to finish it. The jubilee of Pushkin [in 1937] is approaching, but just in those days the idea of a new poem or epic poem was sparkling in my memory. I didn't want to part with the translation, but inspiration made me tackle my own work. (Vurghun 1972, vol. 5: 274)

Vurghun did not consider his work perfect. After finishing it, he wrote: "I consider my work on Eugene Onegin unfinished. In future editions, I shall improve the translation and try to make it better." ${ }^{20}$ Afterwards, in his speech entitled "about the theoretical and practical problems of translation" he finalized his opinion as follows: 
I feel that in my translation, the poetry is not at the same level as it is in the original. 6-7 years have passed since I finished my translation. During these years, I have developed in terms of creativity. It may happen that I shall return to this translation again when I am 50 years old, when I hope to know the secrets of the language perfectly. (Vurghun 1972, vol. 5: 274)

Vurghun returned to his translation not when he was 50 (when in fact he died), but earlier in 1949, on the $150^{\text {th }}$ anniversary of Pushkin's birth: “This year I translated Eugene Onegin for the second time and it is almost new." ${ }^{21}$ It is natural for a poettranslator to return to its translation repeatedly because of the never-ending urge to improve the text of translation.

\section{Translating Poetry: Final Remarks and Conclusions}

In order to summarize the current situation in poetry translation in Azerbaijan, this final section discusses various modes of translation found in Azerbaijan today. These translation philosophies are explained and illustrated.

\subsection{The Translator Between Two Extremes}

In general, the chance for a prominent poet to achieve success in poetic translation is much greater than that of a professional translator with little experience in poetry or an average poet/translator. This is natural, but with the condition that the poet should approach translation work with the same responsibility and inspiration as he/ she does while writing his/her own poems.

Everything depends on the talent and professionalism of the translator, as well as his/her desire (and ability) not to depart too much from the original and to make great efforts to have the poem sound beautiful. Dryden asked a simple question and gave a simple answer while writing his opinions about translation:

Why are there very few acceptable, satisfactory translations? It seems to me that the main reason of this [...] is that there are very few people who possess all the necessary skills for translating and that this important field of art is not appreciated and stimulated much. (Dryden 1992: 22)

Today both translation theory in general and literary translation, especially poetic translation, are full of queries, many of which are related to finding correct and natural passages, bridges and relevance between two literary cultures and two poetic languages.

If the aim of poetry is to express an idea in rhythmic, concise and neat form, then perhaps the aim of translation should be the same. Perhaps the impossible should not even be attempted. Maybe we should abandon poetic translation once and for all, try to perform only philological translation, and be satisfied with giving examples and explanations demonstrating the poet's style and talent in poetic expression. This idea also had and still has supporters (among the most prominent are Longfellow and Nabokov), but their number is very few.

On the other hand, as far as epic poetic works are concerned, there is a need to translate them several times, applying different translation methods. For example, those who want to see Nizami's exact ideas in his works would like to use philological translations. Moreover, on the basis of philological translation done by linguists, 
poet/translators will have the opportunity to attempt their own poetic translation of the work. As Goethe put it: "we have determined that every important poetic work, particularly epic work, should be translated as prose at some time" (Goethe 1980: 408-409).

Another proposal is the idea of looking for the truth in the middle of two extremes. In this case, the form is allowed to be sacrificed in order to remain close and attentive to the original idea. There is no life without sacrifice, and the art of translation is no exception. Of course, it is understandable when small sacrifices provide for the correct resolution of big problems (such as the sacrifice of a pawn in order to capture a queen and attain a victory in chess).

Should literal translation be given priority when translating the idiomatic expressions, metaphors and allegories which comprise the heart of poetry? How should old sayings and idioms be translated: by giving the literal meanings, or by finding an equivalent in the target language?

Berman defends the idea that [o]ld sayings should be translated as they are. It is not right to search for an equivalent in the target language. Let the target language become enriched with the expressions of the source language (Berman (2004: 295). According to Nida (2004: 129), the first case belongs to formal translation, the second, to dynamic translation.

Extraordinariness and beauty of expressions that are brought about by specific historical/cultural circumstances are factors that make the translation of poetic works, which are, in some senses, a game of words, difficult.

\subsection{In Search of Style, Rhythm and Rhyme}

Which poets are translatable? How do differences appear when one translator translates two different poets? Arab writer Ar-Reyhani talks about two kinds of poets: a poet of his time and people, on the one hand, and a poet of all times and all peoples, on the other. Works of the first type lose a great deal during translation, whereas works of the second type are easy for talented translators to handle. The hearts of the second type of poet are not tied to the temporary spirit of their times. This is not characteristic of them. They are the heart and thought of the world (Ar-Reyhani 1988: 265-267).

Of course, translators prefer to translate those poets whom they like and who are close to them in terms of spirit and style. However, Akhmatova does not agree with the absoluteness of this idea: "They used to tell me, 'Akhmatova and V. Hugo - this is impossible.' But in reality you have to translate one that is not similar to you. The real re-shaping is indeed this" (Akhmatova 1986: 436). Akhmatova translated poetry from approximately 30 languages into Russian. It is necessary to note that Soviet writers were engaged with translation work by official orders alongside working to earn their living.

While deciding to translate a work, on the one hand, the translator wants to gain satisfaction from his/her own creativity; on the other hand, he wants to leave a trace by translating a long-lasting work, to "become author or co-author." This responsibility forces the translator to limit his/her freedom in translation and to be sensitive towards the original. Jukovski's translation of the Odyssey, which avoids any kind of embellishment, coloring, or extra effects while remaining loyal to the old image of 
the original without damaging it, can be shown as a very good example of this. This is also an example of exceptional behavior if it is taken into consideration that Jukovski's style of translating poetry was in most cases very free and interpretive.

Vurghun said, "I do not favor it when a translator improves a bad poem through translation." He liked the translation of his famous poem "Azerbaijan" by Adalis, saying "my patriotic spirit and great love that I have toward Azerbaijan are reflected there." However, in discussing a weak translation of his own poem "Partisan Babash," he says that "Azerbaijan" is real poetry in the original, while "Partisan Babash" is not. He considered strengthening a weak poem in translation "a crime before the people," implying that he only wanted good quality poetry to be translated. He said, "I do not need concessions, coloring or enrichment." 22

The desire to preserve the original author's aim as well as the linguistic units and interesting expressions as much as possible, not to weaken the poetic sound of the original, and not to lose the rhythm of the poem, lead to various approaches and to a search for forms in poetic translation. During this search, the translator can sometimes decide to use two or more forms.

In V. A. Jukovski's small poem Pesnya [Song], virtually no rhyming was used, but despite this, the poem has an inner rhythm and sounds like a real song. How can this characteristic be reflected in translation? While translating, there is a need to use some rhyming in accordance with the song tradition of Azerbaijan. Achieving a song-like effect is possible through rhymed words and expressions and establishing musical steps or waves. In this case, it is possible to alternate 8-syllable hemistiches with 7-syllable ones in Azerbaijani (Isaxanli 2005).

Tyutchev's Vesenniye vody [Spring Waters] was also sung by various singers in solo, duet and chorus forms; Rachmaninov's romance on this poem is especially popular. While translating into Azerbaijani the hemistich Vesna idet, vesna idet [Spring is coming, spring is coming], which is repeated twice throughout the poem, again it is possible to use Azeri-style 8-syllable hemistiches (for example Bahar gəlir, bahar gəlir [Spring is coming, spring is coming]). On the other hand, in order to remain closer to the author's words or just to test another form, it is also possible to translate that hemistich as "Spring is on the way, spring is coming" (written Illk bahar yoldadır, ilk bahar gəlir). Thus, in this case, the poem can also be translated using 11-syllable Azeri-style hemistiches and sound differently (Isaxanli 2005).

Returning to the issue of rhyme, those who cannot imagine a poem without rhymes, or at least do not deny the role of rhyming, would probably not like to leave this issue off the agenda, and we should mention their ideas.

While writing a poem, a poet can "allow certain autonomy," because a poem is not meant to express an exact opinion; in order to be more affectionate, rhythmic and easily-remembered, it must have inner music. If the aim is to express a concrete opinion, it could easily be done in uncolored, clear prose. Rhyming and special poetic forms limit the poet's freedom of action. But if, given these limitations, the poet is able to create a beautiful work, then why can the translator not do the same in his/ her native (or the target) language? The autonomy to allow sense and sentiments, coloring, and to not cut a straight path, but to follow the road in a wandering and dancing way, belongs to the translator as well.

It is possible to search for beauty even within limited frameworks. The translator has to construct a new building in a new place (that is, in his/her own language) 
similar to what the poet has already constructed. Of course, this builder should also be an architect to some degree, and should do his/her work with enthusiasm, love and without hurrying. Good luck to the translators who start their voyage with this idea in mind!

As translation activity has no end in itself, ideas, discussions and debates on translation are also endless. To end this article, I would like to refer to Goethe's words again: "Whatever they say about translation work being unsatisfactory, it is one of the most important and most honorable activities uniting the universe" (Goethe 1980: 412).

\section{ACKNOWLEDGMENTS}

I would like to thank my devoted assistant, Martha Lawry, for preparing this article for publication.

\section{NOTES}

1. Also known as Isakhanli; in science (mathematics) the author is also known as Hamlet Isayev, H.A. Isayev, and G.A. Isaev due to different transliterations.

2. The Holy Qur'an (1991). (Translated by Ziya Bunyadov and Vasim Mammadaliyev). Baku: Azerneshr.

3. SAND, George (1833/2004): Kourroglou. Gutenberg. <http://www.gutenberg.org/files/13303/13303$\mathrm{h} /$ 13303-h.htm>; italics in the original.

4. American Philosophical Society (1865): Proceedings of the American Philosophical Society held at Philadelphia for promoting useful knowledge. Vol IX, January 1862 to December 1962. Philadelphia: Sherman \& Co., 8. <https://archive.org/stream/proceedingsofameri09amer\#page/8/mode/2up/ search/mirza>.

5. Terhune, Alfred M. (1947): 212. FitzGerald received it through Burne-Jones only in 1872!

6. Vurghun, Samed (1960): Works, Vol. 2. Baku: Publishing House of the Academy of Sciences of Azerbaijan SSR, 288-289, 291-294.

7. Vurghun, Samed (1977): Izbrannie proizvedeniya [Selected works]. A. S. Quseynova and Q. Q. Reqistan, ed. Moscow: Sovetskiy pisatel, 227-230, 232.

8. Vurghun, Samed (1972): Works, Vol. 5. Baku: Elm Publishing House, 272.

9. Pushkin, Alexander S. (1833/1973): Eugene Onegin. (Translated by Samed Vurghun). Baku: State Publishing House of Azerbaijan.

10. Rustaveli, Shota (1712/1966): A wrestler in tiger's skin (Translated by S. Vurghun, M. Rahim, and S. Rustem). Baku: Azerbaijan State Publishing House.

11. Vurghun, Samed (1972): Works, Vol. 5. Baku: Elm Publishing House, 76.

12. Rustaveli, Shota (1712/1978): A wrestler in tiger's skin (Translated by Ahmed JAVAD). Baku: Elm Publishing House, 13

13. Rustaveli, Shota (1712/2003): A wrestler in tiger's skin (Translated by Imir MammedLI). Baku: Nagil Evi Publishing House.

14. Pushkin, Alexander S. (1833/2003): Yevgeni Onegin [Eugene Onegin]. (Translated by Azer Yaran.) Istanbul: YKY, 3.

15. Vurghun, Samed (1972): Works, Vol. 6. Baku: Elm Publishing House, 175.

16. Vurghun, Samed (1960): Works, Vol. 1. Baku: Publishing House of the Academy of Sciences of Azerbaijan SSR, 241-242.

17. Vurghun, Samed (1972): Works, Vol. 5. Baku: Elm Publishing House, 274.

18. Vurghun, Samed (1972): Works, Vol. 5. Baku: Elm Publishing House, 278.

19. Pushkin, Alexander S. (1833/1986): Sochineniya $v$ trex tomax, tom vtoroj [Works in 3 Volumes, Vol. 2]. Moscow: Khudojestvennaya literatura.

20. Vurghun, Samed (1972): Works, Vol. 5. Baku: Elm Publishing House, 59.

21. Vurghun, Samed (1972): Works, Vol. 6. Baku: Elm Publishing House, 178.

22. Vurghun, Samed (1972): Works, Vol. 5. Baku: Elm Publishing House, 272-273. 


\section{REFERENCES}

Aкнматоva, Alla (1986): Socineniya $v$ dvux tomax [Writings in two volumes]. Vol. 2. Moscow: Khudojestvennaya Literatura.

Alekseev, Vasiliy M. (1985): O poslednyem, 1943 goda, perevode "Evgeniya Onegina" na kitayskiy yazyk [About the latest, 1943: Translation of "Eugine Onegin" into Chinese]. Moscow: Nauka Publishing.

Alembert, Jean le Rond d', «Observations sur l'art de traduire» (1763). French Translators, 1600-1800: An Online Anthology of Prefaces and Criticism. http://scholarworks.umass. edu/french_translators/1

Alimirzeyeva, Flora (1999): The epos Kitabi-Dedem Qorgud in German philological thought. Baku: Elm Publishing House.

Altstadt, Audrey L. (1992): The Azerbaijani Turks: Power and Identity under Russian Rule. Stanford: Hoover Institution Press.

Arnold, Sir Thomas and Guillaume, Alfred, eds. (1931): The legacy of Islam. Oxford: Oxford University Press.

AR-ReyHAni, Amin (1988): Izbrannoe, perevod s arabskogo i anqliyskogo [Selections, translated from Arabic and English]. Leningrad: Khudojestvennaya Literatura.

Baker, Mona and Saldanha, Gabriela, eds. (2009): Routledge encyclopedia of translation studies. London: Routledge.

Berman, Antoine (2004): Translation and the Trial of the Foreign. In: Lawrence Venuti, ed. The Translation Studies Reader. New York/London: Routledge, 284-297.

CAferoglu, Ahmet (1984): Turk dili tarihi [History of Turkish]. Istanbul: Enderun kitab evi.

Delisle, Jean and Woodsworth, Judith, eds. (2012): Translators Through History. Amsterdam: Benjamins.

Dryden, John (1992): On translation. In: Rainer Schulte and John Biguenet, eds. Theories of Translation. Chicago: University of Chicago Press, 17-31.

Ganjavi, Nizami (1192/1981): Leyli and Mejnun. (Translated by Mubariz Alizade.) Baku: Elm Publishing House.

Ganjavi, Nizami (1983): Lyrics. (Translated by Mubariz Alizade.) Baku: Elm Publishing House.

Goethe, Johann Wolfgang von (1980): Pesn` o Nibelunqax. In: Sobraniye Sochineniy [Selected works]. Vol. 10. Moscow: Khudojestvennaya literatura, 408-412.

Grigoryev, Vasiliy V. (1870): Imperial Saint Petersburg University During its First Fifty Years. $\mathrm{SPb}$.

Ibrahimov, Mirza, ed. (1969): Azerbaijanian poetry. Moscow: Progress.

Iвrahimov, Mirza (1982): Introduction. In: Nizami Ganjavi. Leyli and Mecnun. (Translated by Samed Vurghun). Baku: Yazichi, 15-23.

IsAXANLI, Hamlet, ed. (2005): Anthology of Poetical Translation. Vol. 1. Baku: Khazar University Press.

IsAXANLI, Hamlet (2008): Elm ve senet meclisi 1-10 [Assembly of Science and Art 1-10]. Baku: Khazar University Press.

Kazem BeK, Mukhammed Ali M (1985): Izbranniye proizvedeniya [Selected works]. Baku: Elm Publishing House.

Khayyam, Omar (1970): The Rubaiyat of Omar Khayyam. (Translated by Edward FitzGerald). London: The Folio Society.

Koroghlu, Xalik. (1989): Introduction. In: Kniqa otsa nashego Korkuta [Book of our father Korkut]. (Translated by Alla Akhundova). Baku: Yazichi, i.

KrimskiY, Agatangel E. (1981): Nizami i ego sovremenniki [Nizami and his contemporaries]. Baku: Elm Publishing House.

NAĞISOYLU, Möhsün (2000): Orta asrlardə Azərbaycanda tarcümə sənəti [Art of Translation in Azerbaijan in the Middle Ages]. Baku: Elm Publishing House.

NidA, Eugene (2004): Principles of Correspondence. In: Lawrence Venuti, ed. The Translation Studies Reader. New York/London: Routledge, 126-140. 
PICKTHAll, Marmeduke, trans. (1992): The Meaning of The Glorious Koran. New York: Everyman`s Library.

QutQASHINLI, Ismayilbey (1967): Works. (Edited by Aziz Mirahmedov). Baku: Publishing House of the Academy of Sciences of Azerbaijan SSR.

Rosenthal, Franz (1994): The classical heritage in Islam. London: Routledge.

Rzayev, Agababa Kasumoglu. (1989): Mukhammed Ali M. Kazem Bek. Moscow: Nauka.

Schmiede, H. Achmed, Aliyarli, Suleyman, Arazova, Roza et al., eds. (2002): Kitab-i Dedem Qorgud ashiqi [The man in love with Kitab-i Dedem Qorgud ]. Baku: Khazar University Press.

Sehret, Abbas (1912/1991): Introduction to Maghrib Guneshleri [Western Suns]. In: Kamal Talibzade. Selected works in two volumes. Vol. 1. Baku: Azerbaijan State Publishing House, 348.

Seyid-ZAde, Aliajdar A. (1969): Mirza Shafi Vazekh. Baku: Azerbaijan State Press.

Shaig, Abdulla (1912): Gulzar. Baku: Orujov Brothers Press.

Swietochowski, Tadeusz (1995): Russia and Azerbaijan: A Borderland in Transition. New York: Columbia University Press.

Talibzade, Kamal (1991): Selected works in two volumes. Vol. 1. Baku: Azerbaijan State Publishing House.

Terhune, Alfred M. (1947): The Life of Edward FitzGerald. London: Yale University Press.

Tusi, Khaje Nasiraddin (1989): Akhlagi-Nasiri [Nasir's ethics]. Baku: Elm Publishing House.

Velikhanova, Farida (1994): Istoriya perevoda Azerbaydjana [History of translation of Azerbaijan]. Baku: Elm Publishing House.

Venuti, Lawrence, ed. (2004): The Translation Studies Reader. New York/London: Routledge.

Von Grünebaum, Gustave E. (1981): Osnovniye cherti arabo-musulmanskoy kulturu [Basic features of Arabic-Muslim culture]. Moscow: Nauka. 